\title{
Study on the factors influencing minority students' employment in the region
}

\author{
Zhang Guiming \\ Qujing Normal University, Qujing Yunnan,655011
}

Keywords: Minority nationality; Yunnan area; college students; employment area; influencing factors

\begin{abstract}
Our party clearly stated in the eighteen report that we should do a good job of graduate employment, so that more graduates can successfully obtain employment when they graduate. All along, the rate of employment in Colleges and universities has become one of the issues that our party and government pay close attention to, and the major colleges and universities should include the ability to train students' employment and entrepreneurship to be included in the target of personnel training. However, minority colleges and universities are also the main tasks to train high-quality talents of ethnic minorities. Therefore, how to improve the employment of minority college students has become one of the urgent problems for minority colleges and universities. This paper analyzes and studies the factors influencing the employment of minority college students, and puts forward the employment guidance strategy for minority students.
\end{abstract}

\section{Introduction}

Minority college students occupy a large proportion of college students in our country. In order to cultivate more talented people of minority nationalities, China has formulated a preferential policy applicable to ethnic minorities. At the same time, for the minority college students to obtain higher teaching quality, but also invested more funds for education. This paper explores the employment of minority students in Yunnan area and the existing factors, minority college students' employment problems are analyzed, finally put forward the corresponding strategies, hoping to help more minority students better employment[1].

\section{Minority student's employment regional impact factors}

After studying the graduate employment situation of minority college students, it is found that their national emotional factors are one of the obvious factors that affect employment. Concretely speaking, when a minority college student has more profound ethnic feelings, he is more willing to work in his own ethnic areas. Through the investigation of students work in ethnic minority areas is not difficult to find work here, students are very fond of their own nation, have a strong sense of national pride, they think themselves bear the heavy task of development of ethnic minority areas, their own national culture inheritance. So they choose to work in ethnic areas, and in their eyes, it is more important to inherit the national culture than to pursue their personal achievements. It is precisely because they have this spirit, only let them inherit and carry forward the broad and profound culture of our ethnic minorities[2].

After national emotion, Kern in second is the factors of employment opportunities. This has become the second important factors that affect the employment of Minority College students. We have found that if there is a job opportunity, minority students can work in ethnic minority areas. Almost eighty-six percent of minority students are willing to work in ethnic areas. Thus, the employment opportunity has become an important factor in the selective employment of ethnic minority college students. Employment opportunities include the following two aspects, the first is the appropriate time or opportunity, in this regard, more emphasis on minority college students job hunting strategies and related skills training. The second aspect refers to the training of College 
Students' employability. That is to say, the employment opportunity we refer to refers to the employment competitiveness of College students. So, for the minority colleges, the minority college students training, to the training mode, teaching methods and means of management service personnel from the aspects of training, in order to improve the university students learning competition ability, increase employment opportunities for college students.

Professional achievement factors have become the third important factors after the national emotional factors and employment opportunities. In the process of investigation and research, it is found that professional achievements will become a major factor for minority students to choose to work in ethnic areas. This is because the professional achievement factors is one of the main factors of minority college students in their employment evaluation, usually minority students according to their own professional achievements to choose whether or not to return to the nation area or village to the civil service exam, employment. At the school employment guidance on this issue to their role into full play, because for minority students, all of them are from minority areas, due to geographical restrictions, cultural differences and other factors, the first challenge for minority college students is learning problems, they not only need to spend more the energy in the professional study and master, also need to adapt to the environment, improve the quality and ability of the person. In job hunting is particularly confused, so the school employment guidance should be promptly given to them for their help and guidance[3].

Family income is one of the fourth factors that affect the employment of minority students. In the investigation we found that minority students with higher family income will be more willing to work in non ethnic regions, and those of lower income minority students will choose to work in the minority areas. This is due to the fact that most of them are born in one of the townships or towns in their ethnic areas. What if he chose to work in non ethnic regions after graduation, so they have to bear the pressure of life is relatively large, but because of their family income is limited, it is difficult for them in the non minority areas of life to help, so they tend to go to work in ethnic minority areas.

National policy factors are also a major factor affecting the employment areas of minority students. Its specific performance is to understand the preferential policies of the state, the more the number of minority students, the more willing to work in ethnic areas. In recent years, in order to further solve the problem of College Students' employment, China has promulgated a lot of preferential policies for graduates' employment. For example, college student loans, special post teacher subsidies, "college students as village officials", "College Students' preferential policies for self employment" and so on. Although these preferential policies have some influence on the employment choices of some minority college students, they also find that some minority students are not clear about these policies. In this case, minority college students should be prepared for employment, more information, and then choose the most suitable employment direction.

\section{Aiming at the regional factors influencing the employment of minority college students, the effective strategies are put forward}

In the survey we found that most of the minority college students from rural areas, their parents' cultural level is not high, some even if do not know, in the use of Chinese is also very awkward. Therefore, the departments of ethnic minority areas should make joint efforts with ethnic minority colleges and universities to develop a Chinese language training program for ethnic minority students. First of all, for the government, we should increase investment in education, and use the bilingual education of minority students to improve their proficiency in chinese. At the same time in the university stage, minority colleges should be in communication and coordination with the government, enterprises and institutions engaged in training of personnel employment terms of minority college students, let the minority college students in employment before the master Chinese language and common language professional, convenient in employment of college students after work. In addition, the school also should pay attention to the Chinese propaganda work in the school, such as Chinese newspaper column, to carry out the Chinese learning Chinese speech contest held in June, and so on, it is conducive to the minority students to learn Chinese and 
improve their Chinese level, but also conducive to the Chinese students to learn more about the customs and culture of minority students habit[4].

The Chinese government has attached great importance to the employment of Minority College students. In 2013, Premier Li Keqiang made an inspection visit to Lanzhou University and suggested that minority students should be encouraged to work in the minority areas. Most of the minority students in Yunnan are from the Yunnan area. They understand the actual situation in the region, and through the careful training of colleges and universities, they have certain ability and business. If our government is to further improve its preferential employment policies, they will be very willing to return to the region for employment. In this way, when they are employed, it is more convenient to communicate with and communicate with local people. There will be no language differences, cultural differences, habits and other issues. So in this regard, the Chinese government for employment of minority college students, should be given more preferential policies, such as providing minority college students of minority college students more practice opportunities, the return to work in minority areas given priority admission and use arrangements, to work in the poor environment to provide more material guarantee for the minority college students obtain official posts relax restrictions. Through this method, it can not only meet the employment desire of minority students returning to their own ethnic areas, but also increase their employment status. I believe that with the support of the powerful policy of the government, more and more minority students will be willing to return to work in their ethnic areas and contribute themselves to the development of their ethnic areas[5].

We are for those who want to employment after graduation and are not willing to study the minority college students in school, the school should be based on their employment needs of the school's professional re setting or adjustment, increased and expanded the employment needs of higher professional, reduce and narrow those who do not meet the employment needs of professional. Especially for those who are unwilling to study this major or are dissatisfied with their major, the minority students should make timely professional adjustments. At the same time, schools should provide students with more opportunities to double degree and promote their growth. Colleges and universities how to set up and adjust the specialty according to the needs of employment, should be from the following aspects: first, the school should expand the channels of information, enterprises understand the current high demand for minority college is presented, followed by professional setting and adjustment, so that talents can be more in line with market demand. For example, we can track the graduates, and then adjust the teaching content according to the investigation, in order to achieve the effective docking between talent training and employment. Second, the professional setting itself is a more complex work, it is not only related to the overall development of colleges and universities, but also closely related to the vital interests of the majority of teachers. Therefore, every teacher in the university should be actively put into the professional setting of the school to innovate the teaching idea and fully realize the task of the applied school. Finally, colleges and universities should take employment as the guide, and develop the teaching materials in accordance with the characteristics of minority students and the needs of enterprises. The use of teaching materials in Colleges and universities in China has certain universality, lack of pertinence, more theoretical content, practicality is very poor, not to the actual situation of the enterprise and the students reflected the lack of flexibility. So the university should carry on the reform and innovation of teaching content, from the development of students, students' employment needs and the actual needs of the employer, developed with pertinence, practicability and maneuverability of the textbooks, teachers should improve the teaching design and development ability in the teaching process, to achieve zero the distance between teaching content and post demand.

According to the latest development plan of the Ministry of education, undergraduate students are likely to be classified in the future, that is to say, two kinds of undergraduate, atmosphere, research and technology should be taken. In this case, as a National University, if the conditions permit, it can be transformed to the application-oriented institutions according to the actual employment needs of the local, and train skilled talents for the Yunnan region. After graduation, 
these minority students can quickly integrate into the local job market and find their own work units. At the same time, it also improves the quality of talents in minority areas. 5. institutions of higher learning can regularly organize students to visit and study in enterprises and institutions

According to the survey, only thirteen percent of the students have a strong passion for their chosen profession and are willing to work hard to study it. And sixteen percent of the students are very dissatisfied with their choice of professional, and even bored. There are also some students who believe that what they have learned is not related to what they want to do in the future. For minority students, they are usually more willing to employment in the ethnic areas where parents, not only because they can take care of parents, because they are more familiar with the environment, work more convenient. Therefore the national colleges should actively communicate with the local government, in cooperation with government departments and enterprises signed an agreement, and then organize the students regularly to the local enterprises to visit and study, understand the current environment of enterprises and institutions for staff requirements, salary, working time and so on, it can also help the minority minority college students have a clear understanding of their future employment situation.

\section{Conclusion}

All in all, in the current difficult employment background, we analyze the influencing factors of regional employment of minority college students, to explore these factors influenced an important role in improving the minority college employment rate is very necessary. At the same time when we explore, put forward higher requirements but also the work content of minority college students employment guidance, hope they can work for the innovation mode, employment guidance of minority students.

\section{Acknowledgements}

Project supported by the youth research foundation of Qujing Normal University in 2014, "study on the employment outlook of minority students in Qujing Normal University" (item number: 2013QN005)

\section{References}

[1]Mead L S, Clarke J B, Forcino F, et al. Factors influencing minority student decisions to consider a career in evolutionary biology[J]. Evolution Education \& Outreach, 2015, 8(1):6.

[2]Matti F M A. Factors Affecting Minority Students' Persistence in Community Colleges.[J]. Academic Achievement, 2000:146.

[3]Galatia Theodosiou-Zipiti, Mel West, Daniel Muijs. Factors affecting ethnic minority students' attainment in secondary schools in Cyprus: a focus group study[J]. Intercultural Education, 2010, 21(5):483-489.

[4]Houser C S, An S. Factors Affecting Minority Students' College Readiness in Mathematics.[J]. Urban Education, 2015, 50(8).

[5]Pate J C. Factors influencing minority students to enroll in technical programs in the Kentucky Community and Technical College System[J]. Dissertations \& Theses - Gradworks, 2009. 